\title{
Hypoxia Increases the Expression of Stem-Cell Markers and Promotes Clonogenicity in Glioblastoma Neurospheres
}

\author{
Eli E. Bar, ${ }^{*}$ Alex Lin, ${ }^{*}$ Vasiliki Mahairaki, ${ }^{*}$ \\ William Matsui, ${ }^{\dagger}$ and Charles G. Eberhart*†‡ \\ From the Departments of Pathology,* Oncology, ${ }^{\dagger}$ and \\ Ophthalmology, Johns Hopkins University School of Medicine, \\ Baltimore, Maryland
}

\begin{abstract}
Hypoxia promotes the expansion of non-neoplastic stem and precursor cell populations in the normal brain, and is common in malignant brain tumors. We examined the effects of hypoxia on stem-like cells in glioblastoma (GBM). When GBM-derived neurosphere cultures are grown in $1 \%$ oxygen, hypoxia-inducible factor $1 \alpha($ HIF $1 \alpha)$ protein levels increase dramatically, and mRNA encoding other hypoxic response genes, such as those encoding hypoxia-inducible gene-2, lysyl oxidase, and vascular endothelial growth factor, are induced over 10-fold. Hypoxia increases the stem-like side population over fivefold, and the percentage of cells expressing CD133 threefold or more. Notch pathway ligands and targets are also induced. The rise in the stem-like fraction in GBM following hypoxia is paralleled by a twofold increase in clonogenicity. We believe HIF1 $\alpha$ plays a causal role in these changes, as when oxygen-stable HIF1 $\alpha$ is expressed in normoxic glioma cells CD133 is induced. We used digoxin, which has been shown to lower HIF protein levels in vitro and in vivo, to inhibit the hypoxic response. Digoxin suppressed HIF1 $\alpha$ protein expression, HIF1 $\alpha$ downstream targets, and slowed tumor growth in vivo. In addition, pretreatment with digoxin reduced GBM flank xenograft engraftment of hypoxic GBM cells, and daily intraperitoneal injections of digoxin were able to significantly inhibit the growth of established subcutaneous glioblastoma xenografts, and suppressed expression of vascular endothelial growth factor. (Am J Pathol 2010, 177:1491-1502; DOI: 10.2353/ajpath.2010.091021)
\end{abstract}

Glioblastoma (GBM) is the commonest malignant brain cancer in humans, with most patients succumbing to disease within 1 or 2 years of diagnosis. ${ }^{1,2}$ Cells with stem-like properties have been isolated from freshly resected human GBM, and can be efficiently propagated in defined media. ${ }^{3-5}$ This subset of neoplastic cells, which appear to be resistant to standard therapies and endowed with increased clonogenic potential, are often called cancer stem cells (CSC). It has been suggested that the persistence of CSC after treatment may explain why tumors recur, and that only by their eradication can a neoplasm be successfully cured. ${ }^{6-8}$ Treatments causing CSC to differentiate or die therefore represent a novel therapeutic avenue with great promise. To achieve this, several groups have investigated if pathways affecting normal stem cells such as Hedgehog, Notch, and bone morphogenetic protein can be targeted in brain tumors, with some positive results in preclinical models. ${ }^{9-16}$

Oxygen levels play an important role in regulating stem cells in multiple tissues, including the nervous system (recently reviewed in 17), and the hypoxic response represents another potential therapeutic target in brain tumor CSC. Growth under low oxygen concentrations is known to maintain pluripotency and inhibit the differentiation of embryonic stem cells. ${ }^{18}$ In the rodent brain and neural crest, reduced oxygen levels promote the survival and clonogenic growth of stem and progenitor cells, and can modulate their differentiation. ${ }^{19,20}$ Hypoxia also promotes the expansion of human central nervous system precursor cells. ${ }^{21}$ Given the often similar properties between non-neoplastic and neoplastic neural stem cells, these data suggest that reduced oxygen levels might promote the specification, survival, and/or proliferation of CSC in brain tumors.

Supported by the James S. McDonnell Foundation/Brain Tumor Funders Collaborative and the National Institutes of Health (grant NS055089).

Accepted for publication May 14, 2010.

None of the authors disclosed any relevant financial relationships.

Supplemental material for this article can be found on http://ajp. amjpathol.org

Address reprint requests to Eli E. Bar, Ph.D., Johns Hopkins University School of Medicine, Department of Pathology, 400 N. Broadway, Smith Building 4027, Baltimore, MD 21287. E-mail: ebar1@jhmi.edu. 
In the brain, physiological oxygen concentrations vary from $0.5 \%$ to $7 \% .{ }^{22-24}$ Hypoxic regions are common in malignant brain tumors such as glioblastoma, and are thought to play an important role in several facets of tumor pathobiology (reviewed in 25). Indeed, hypoxic necrotic foci with pseudopalisading tumor cells are one of the features that define GBM in the current World Health Organization classification scheme. Tumor hypoxia has been associated with resistance to radiation and chemotherapies in GBM, as well as tumor invasion and poor patient survival. ${ }^{25-31}$

While levels of oxygen vary within brain tumors, it seems clear that all high grade gliomas contain numerous foci that are hypoxic as compared with surrounding brain. Evans and colleagues ${ }^{32,33}$ measured oxygen levels in gliomas using EF5 binding and Eppendorf needle electrodes. They define mild hypoxia in brain tumors as ranging from $0.5 \%$ to $2.5 \%$ oxygen, moderate hypoxia as ranging from $0.1 \%$ to $0.5 \%$ oxygen, and severe hypoxia/ anoxia as $0.1 \%$ oxygen or less. In one study including 12 GBM, 5 tumors (42\%) had foci with severe hypoxia. ${ }^{34}$ Among the three GBM analyzed in their second study, the majority of the regions sampled had mild or moderate hypoxia. ${ }^{32}$ Other studies using microelectrodes to measure oxygen levels in GBM have documented median $\mathrm{pO}_{2}$ levels corresponding to $1 \%$ oxygen or less. ${ }^{35,36}$

The cellular response to hypoxia is controlled by hypoxia inducible factors $1-3 \alpha$ (HIF1-3 $\alpha),{ }^{37}$ which heterodimerize with the constitutively expressed $\mathrm{HIF} 1 \beta$ (ARNT). Under atmospheric oxygen concentration, HIF1 $\alpha$ is hydroxylated on specific proline residues (Pro402, Pro-564), ubiquitinated by the Von-Hippel-Lindau tumor suppressor gene, and rapidly degraded by the 265 proteasome. ${ }^{38,39}$ Under hypoxia, the activity of the prolyl-hydroxylases is inhibited and the affinity of VonHippel-Lindau to HIF $\alpha$ is reduced, resulting in rapid accumulation of the HIF $\alpha$ protein (reviewed in 29). In this study, we examine the effects of hypoxia on glioma neurosphere cultures, and show that reduced oxygen levels increase the CSC fraction. We also exploit the recent discovery that digoxin can lower the levels of $\mathrm{HIFs}^{40,41}$, and find that this cardiac glycoside inhibits glioma growth in vitro and in vivo.

\section{Materials and Methods}

\section{Low Passage Primary GBM Cultures, Established Neurosphere Lines, and Hypoxic Conditions}

The GBM neurosphere lines HSR-GBM1 (also designated 020913) and HSR-GBM2 (also designated 040622) were a kind gift from Dr. Angelo Vescovi and were maintained in Neurocult complete (Stem Cells Tech., Vancouver, BC, Canada) essentially as previously described. ${ }^{3}$ For establishment of low passage neurosphere cell lines, fresh surgical material was acquired with permission from the Johns Hopkins Hospital Institutional Review Board. Tissue was processed and propagated essentially as previously described. ${ }^{3}$ Growth medium used for propa- gation of these cultures is Neurocult complete (Stem Cells Tech), supplemented with human fibroblast growth factor, human epidermal growth factor $(10 \mathrm{ng} / \mathrm{ml}$ each, Peprotech, Rocky Hill, NJ), and $0.002 \%$ (w/v) heparin sulfate (Sigma, St. Louis, MO). These neurosphere cultures have been grown continuously for over 20 passages in our laboratory, evidence of their long-term self renewal potential. In vitro hypoxic experiments were performed in a temperature and humidity-controlled hypoxic chamber set at $1 \% \mathrm{O}_{2}, 5 \% \mathrm{CO}_{2}$, and $94 \% \mathrm{~N}_{2}$ (COY laboratory equipment, Grass Lake, MI). The apparatus contains a separate access chamber, as well as two pairs of work gloves, allowing manipulation of cultures in a continuously hypoxic environment.

\section{Lentivirus Preparation and Infection}

Lentiviruses were generated essentially as previously described. ${ }^{42}$ Briefly, the HIV-1 lentiviral vector containing the oxygen insensitive variant of $\mathrm{HIF}-1 \alpha$ ( $\left.\mathrm{HIF}-1 \alpha^{\mathrm{P} 402 \mathrm{~A} / \mathrm{P} 564 \mathrm{~A}}\right)$ and empty vector control were provided by Dr. Westerman (Harvard Medical School, Boston, MA). Lentivirus vectors containing short hairpins against HIF1 $\alpha$ and luciferase control were provided by Dr. Chumakov (Cleveland Clinic, Cleveland $\mathrm{OH}$ ). HIF1 $\alpha$ expressing virus was produced by first transfecting 293T cells with $3.2 \mu \mathrm{g}$ of vector, $4.0 \mu \mathrm{g}$ of the packaging plasmid, and $0.4 \mu \mathrm{g}$ of REV, TAT, and VSV-G. The growth medium was replaced with Neural Stem Cell medium 16 hours post-transfection and 48 hours later, cell supernatants were collected and filtered through a $0.22-\mu \mathrm{m}$ filter. HSR-GBM1 cells were plated at a density of $2 \times 10^{5}$ cells/well of a 6 -well plate 24 hours before transduction, then transduced using $2 \mathrm{ml}$ of viral supernatants supplemented with $8 \mu \mathrm{g} / \mathrm{ml}$ polybrene (Sigma, St. Louis, MO). To isolate individual subclones, cells were triturated and then plated in 96-well plates at a density of 0.7 cells/well. Single subclones were analyzed by Western blot analysis for the presence of elevated HIF1 $\alpha$ expression under normoxia.

\section{RNA and Protein Analyses}

RNA levels were analyzed by real-time PCR analysis performed in triplicate with SYBR Green reagents (Applied Biosystems, Foster City, CA) according to the manufacturer's instructions on an I-Cycler IQ5 real-time detection system (Bio-Rad, Hercules, CA). To minimize contaminating genomic DNA, a 15-minute on-column DNase step (Qiagen RNase-free DNase kit) was included during RNA extraction. The standard curve method was used to determine expression levels, and all values were normalized to actin. Oligo sequences were as follows: human Lysyl oxidase $(\mathrm{LOX})^{3}$; human vascular endothelial growth factor (VEGF) forward: 5'-TGCCCGCTGCTGTCTAAT-3'; human VEGF reverse: 5'-TCTCCGCTCTGAGCAAGG-3'; human hypoxia-inducible gene (HIG)2 forward: 5'-CCGACTTTCCTCCGGACT-3'; human HIG2 reverse: 5'-CCTTCTGAAAGGCCTCTGG-3'; human prominin1 (CD133) forward: 5'-TCCACAGAAATTTACCTACATTGG-3'; CD133 reverse: 5'-CAGCAGAGAGCAGATGACCA-3'; human 
KLF4 forward: 5'-CCATCTTTCTCCACGTTCG-3'; human KLF4 reverse: 5'-AGTCGCTTCATGTGGGAGAG-3'; human SOX2 forward: 5'-TTGCTGCCTCTTTAAGACTAGGA-3'; human SOX2 reverse: 5'-CTGGGGCTCAAACTTCTCTC-3'; human actin- $\beta$ forward: 5'-CCCAGCACAATGAAGATCAA-3'; and human actin- $\beta$ reverse: 5'-GATCCACACGGAGTACTTG- 3'.

Immunoblot analysis of HIF1 $\alpha$ (catalog number 610959, 1:1000; BD Biosciences Franklin Lakes, NJ), Prominin1 (CD133, clone ab19898, 1:500, Abcam, Cambridge, MA), and glyceraldehyde-3-phosphate dehydrogenase (clone 6C5, 1:500,000; Research Diagnostics, Concord, MA) was performed on lysates $(50 \mu \mathrm{g})$ prepared using standard techniques at indicated time points after hypoxic exposure and quantified using Image $\mathrm{J}$ densitometry software. ${ }^{42}$

\section{Fine Needle Aspirates and in Vivo Tumor Engraftment}

For fine needle aspirate studies profiling acute tumor response, HSR-GBM1 xenografts were allowed to form for a period of 3 weeks, at which point mice were treated with PBS or $2 \mathrm{mg} / \mathrm{kg}$ digoxin (Baxter, Deerfield IL) for 2 days (two mice per group). Small aspirates of tumor material were taken using an $18 \mathrm{~g}$ hypodermic needle just prior to and 2 hours after treatment. Aspirated tissues were collected in Neuro Stem Cell (NS) complete medium (StemCell Technologies, Vancouver BC, Canada) ${ }^{3}$ supplemented with $0.002 \%$ heparin, $10 \mathrm{ng} / \mathrm{ml}$ human epidermal growth factor, and $10 \mathrm{ng} / \mathrm{ml}$ human fibroblast growth factor-b (Peprotech, Rocky Hill, NJ) (NS-complete) and then snap-frozen in dry ice.

To test the effect of digoxin pretreatment on tumor cell engraftment, HSR-GBM1 cells were exposed in vitro to $100 \mathrm{nmol} / \mathrm{L}$ digoxin or PBS. A day after drug treatment began, cells were placed in hypoxia (1\% oxygen) for 48 additional hours. Treated cells were washed once and then plated back in fresh medium and allowed to recover for 24 hours in normoxia. The next day, flank xenografts were established by subcutaneous injections of $1 \times 10^{5}$ cells per flank by suspending PBS- or digoxin-treated cells in $200 \mu \mathrm{l}$ growth-factor-reduced Matrigel (BD Bioscience) diluted 1:1 with NS-complete medium (5 mice per group). Tumor volume was calculated using the formula $V=L^{*} W^{2} / 2$ following methods previously described by others. ${ }^{45}$

\section{Flow Cytometric Analyses}

For CD133 flow cytometric analysis, cells were exposed to hypoxic conditions for 24,48 , and 72 hours. Cells were collected at $276 \times g$ for 10 minutes, triturated, and processed for AC133/PE antibody staining as previously described. ${ }^{10}$ For side population analyses, HSR-GBM1 cells were exposed to hypoxia for 24 hours. Side population analyses on treated cells were performed as previously described. ${ }^{10}$

\section{Clonogenic and Cell Growth Assays}

HSR-GBM1 cells were seeded in $775 \mathrm{~cm}^{2}$ culture dishes at $3.75 \times 10^{5}$ cells per dish in $10 \mathrm{ml}$ of NS-complete medium. Dishes were incubated upright for 7 days in a humidified incubator with $5 \% \mathrm{CO}_{2}$ at $37^{\circ} \mathrm{C}$. Clonogenic assays were performed in 6-well plates that were precoated with $200 \mu \mathrm{l}$ of $2 \mathrm{mg} / \mathrm{ml}$ poly (2-hydroxyethyl methacrylate) (Sigma, St. Louis, MO) in 95\% ethanol. The plates were allowed to dry at $37^{\circ} \mathrm{C}$ over several days. One hour before use, wells were washed once with $2 \mathrm{ml}$ of PBS, then overlaid with $2 \mathrm{ml}$ of neuro stem-cell methyl cellulose, which is NS-complete supplemented with 1.5\% methyl cellulose (Fisher, catalog number M-352, Pittsburgh, PA). This layer served as the "base" layer. The plates were incubated for 1 hour at $37^{\circ} \mathrm{C}$ before plating. Cells were resuspended in NS-complete, mixed 1:4 with NSMC, and plated in $2 \mathrm{ml}$ at $1 \times 10^{4}$ cells/well. Cells were fed $0.5 \mathrm{ml}$ of NSMC every 2 to 3 days. Subsequent sphere formation was monitored and scored by light microscopy after 10 to 12 days. Sphere diameter was scored and spheres were aspirated based on size using pulled pasture pipette. Spheres were then pulled according to diameter, triturated, and plated as described above. The size of the secondary spheres was scored as described above.

For clonogenic assays done post hypoxia, HSR-GBM1 and HSR-GBM2 cells were exposed to hypoxic conditions for 24 hours, transferred to normoxia for 24 hours and then processed as described above. Ten to 12 days later, 10 random fields were photographed in triplicate wells for each condition. Sphere diameter was measured at the two longest perpendicular axes of each sphere and those values were averaged to produce the average sphere diameter value. All measurements were performed using Motic AE31 light microscope equipped with a Moticam 2300 camera and analyzed using the Motic Images-Plus Version 2.0 software package (Motic Instruments, Richmond, BC, Canada).

Cell growth was measured using CellTiter-96 Non-Radioactive Cell Proliferation Assay (Promega, Madison, WI). Fold increase in viable cell mass was calculated by dividing A490 absorbance at end point (day 5) to that observed on day 1.

\section{Statistics}

Two sided $t$-tests and frequency distributions were performed using GraphPad software. Unless otherwise noted, error bars represent SEM for (at a minimum) triplicate experiments.

\section{Results}

Hypoxia Induces Expression of the Neural Stem Cell Marker CD133

To test the effect of hypoxia on stem-like cancer cells, we exposed the established GBM neurosphere lines HSRGBM1 and HSR-GBM2, as well as initial passage (P1) 
GBM cells isolated from three fresh surgical resections, to hypoxia $\left(1 \% \mathrm{O}_{2}\right)$ for 72 hours. We noted increases in the expression of multiple genes known to be regulated by hypoxia. LOX showed an 8- to 46-fold increase in
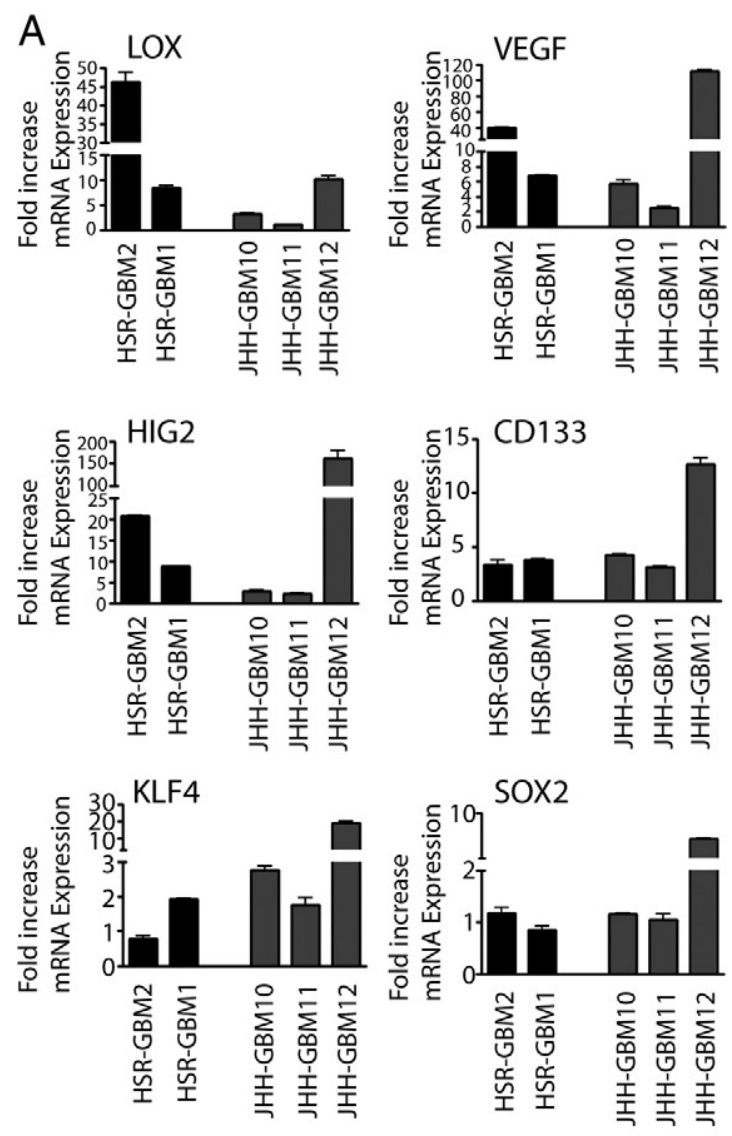

B

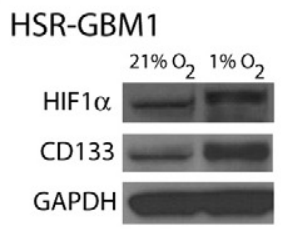

C
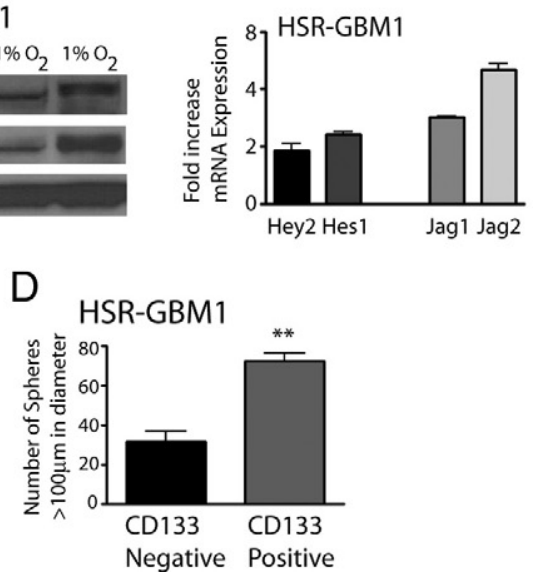

Figure 1. Hypoxia positively upregulates mRNA levels of lysyl oxidase (LOX), Vascular Endothelial Growth Factor (VEGF), Hypoxia Induced 2 (HIG2), and Prominin1 (CD133), and in some cells KLF4 and SOX2 in the established glioma neurosphere lines HSR-GBM2 and HSR-GBM1, and in freshly resected, GBM tumors, JHH-GBM10, JHHGBM11, and JHH-GBM12. All data was normalized to $\beta$-actin and is represented as relative expression (relative to normoxia; $\mathbf{A}$ ). Twenty-four hours exposure to hypoxia induces HIF1 $\alpha$ and CD133 protein expression in HSR-GBM1. GAPDH was used as a protein loading control (B). In HSR-GBM1, hypoxia positively upregulates mRNA levels of the Notch ligands, JAG1 and JAG2, as well as its targets, Hey2 and Hes1 (C). In HSR-GBM1, CD133-positive cells are two-fold more clonogenic in comparison with CD133negative cells as indicated by a 2 -fold increase in the development of large $(>100 \mathrm{~mm})$ CSC containing spheres $\left({ }^{* *} P<0.01\right.$, two sided $t$-Test; $\left.\mathbf{D}\right)$.
mRNA levels in established GBM neurosphere lines, and up to 10-fold increases in initial passage cultures (Figure 1A). VEGF and HIG2 showed similarly dramatic increases (Figure 1A). Importantly, we found that the stem cell markers CD133, Klf4, and Sox2 were also induced, showing up to 20-fold mRNA increases in most of the five cultures tested (Figure 1A). Next, we confirmed that CD133 protein levels are induced by growth in low oxygen. Figure 1B shows representative Western blots of HSR-GBM1 lysates prepared from cells grown in hypoxic condition for 48 hours. Similar results obtained in cultures grown in $1 \%$ oxygen for 24 or 72 hours (data not shown). Because Notch signaling can promote stem-like characteristics in glioma cells, ${ }^{16,46,47}$ and Notch has also been associated with hypoxia, ${ }^{43}$ we examined expression of Notch pathway members in reduced oxygen. The Notch ligands Jag1 and Jag2, as well as in the downstream targets Hey2 and Hes1, were all induced several-fold (Figure 1C).

To investigate the effects of hypoxia at a single cell level, we exposed GBM neurospheres and freshly dissected tumor cells to $1 \% \mathrm{O}_{2}$ for 72 hours and then performed flow cytometric analysis to determine the percentage of CD133positive cells. When HSR-GBM1 cells were sorted using fluorescence-activated cell sorting (FACS), the CD133positive fraction had a two-fold higher clonogenic potential than the CD133-negative fraction (Figure 1D), indicating that CSC are enriched to a significant degree in this population. Growth in reduced oxygen increased the percentage of CD133-positive cells from $31 \%$ to $92 \%$ in the HSR-GBM1 parent line (data not shown), and from $42 \%$ to $87 \%$ in HSR-GBM1 vectortransfected control cells (mean, $45.4 \pm 2.8$ in normoxia to $90.2 \pm 1.5$, Figure $2 \mathrm{~A}$ ). Interestingly, we found that these cultures transiently grown in hypoxic conditions maintained an elevated percentage of CD133-positive cells $(92 \%)$ even seven days after return to $21 \%$ oxygen-

A
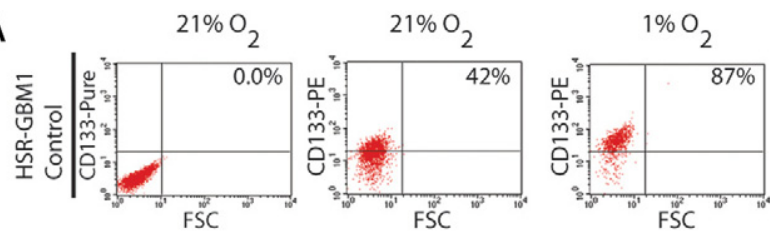

B
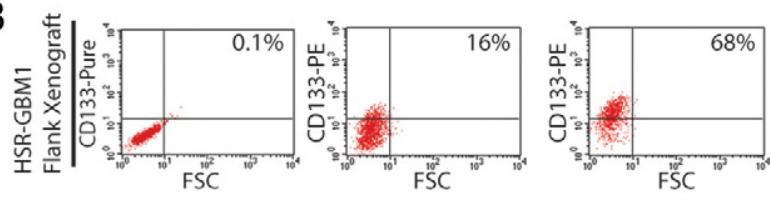

C
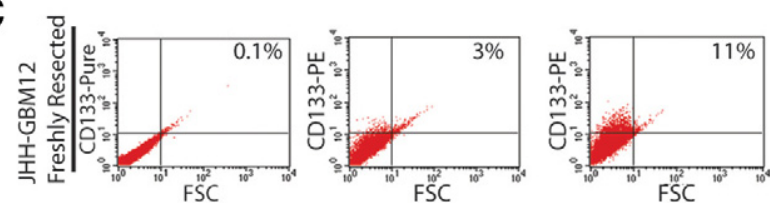

Figure 2. When the established neurosphere line HSR-GBM1 (A), xenograft isolated HSR-GBM1 (B) or freshly resected JHH-GBM12 (C) cells were exposed to hypoxia for 24 hours, the percentage of CD133-positive cells as measured by flow cytometric analysis increased 2-, 4-, and threefold, respectively. With the exception of JHH-GBM12, all experiments were repeated at least three times with similar results. Unconjugated CD133 (pure) was used as threshold control. 
ation (data not shown). These data suggest that hypoxiainduced CD133 expression is relatively stable.

It is possible that GBM cells freshly isolated from either animal xenografts or primary human tumors better represent the biology of the tumors than longer-term cultures lacking stroma or other in vivo elements. We therefore tested the effects of hypoxia on CD133 fraction in HSRGBM1 cells freshly isolated from flank xenografts propagated in nude mice. Interestingly, the percentage of tumor cells expressing CD133 was reduced somewhat following a period of in vivo growth (Figure 2B). However, as was seen in continuously cultured neurospheres, when cells directly isolated from xenografts were grown for 3 days in hypoxia the percentage of CD133-positive cells was significantly higher (68\%) as compared with parallel cultures grown in normoxia $(16 \%$, mean $=18.2 \pm$ 2.7 in normoxia to $65.2 \pm 2.7$, Figure $2 \mathrm{~B}$ ). Finally, in $\mathrm{JHH}-\mathrm{GBM} 12$, a freshly resected primary human tumor, hypoxic exposure increased the CD133 percentage from $3 \%$ to $11 \%$ (Figure $2 \mathrm{C}$ ). The threefold, 4.2 -fold, and 4.4-fold induction in CD133-positive fractions for these three experiments suggests that both freshly dissociated in vivo tumors and longer term neurosphere cultures can behave similarly when subjected to hypoxic growth conditions.

\section{HIF1 $\alpha$ Is Sufficient for Hypoxia-Induced CD133 Expression}

HIFs are master regulators of the transcriptional response to hypoxia. We therefore explored the possibility that HIF1 $\alpha$ may play a causal role in the induction of CD133 in response to hypoxia. To this end, we stably infected HSR-GBM1 with a lentiviral construct encoding an oxygen stable double mutant, HIF1 $\alpha^{\text {P402A/P564A }}$ (a kind gift of Dr. Karen Westerman). Under normal oxygen conditions, HIF1 $\alpha$ protein level is low in HSR-GBM1 cells but is rapidly increased following exposure to hypoxia (Figure

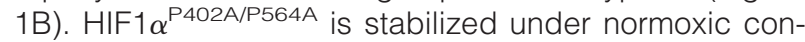
ditions as it lacks the crucial proline residues that are targeted by PHD1-3. ${ }^{45}$ We isolated two stable subclones expressing elevated levels of HIF1 $\alpha^{\text {P402A/P564A }}$ (HSRGBM1 C5 and E11). In analyses of early passages of the subclones, HSR-GBM1 C5 HIF1 $\alpha$ protein levels were lower than those in HSR-GBM1 E11, but both showed equivalent elevations in later passages. Consistent with our hypothesis, HIF1 $\alpha^{\text {P402A/P564A }}$ expression in normoxic conditions resulted in increased CD133 protein levels as assessed by Western blot (Figure $3 \mathrm{~A}$ ) and increasing percentages of CD133-positive cells (C5 mean $=61.0 \pm$ 9.0, E11 mean $=92.0 \pm 2.5$, Figure 3B). These data indicate that $\mathrm{HIF} 1 \alpha$ activity is sufficient to induce CD133 expression and elevate the stem-like tumor subpopulation in response to hypoxia.

\section{Hypoxia Increases the Percentage of GBM Side-Population Cells}

We next explored the possibility that in addition to CD133, other stem/progenitor cell markers may also be
A
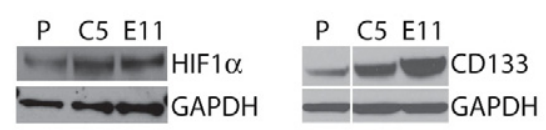

B
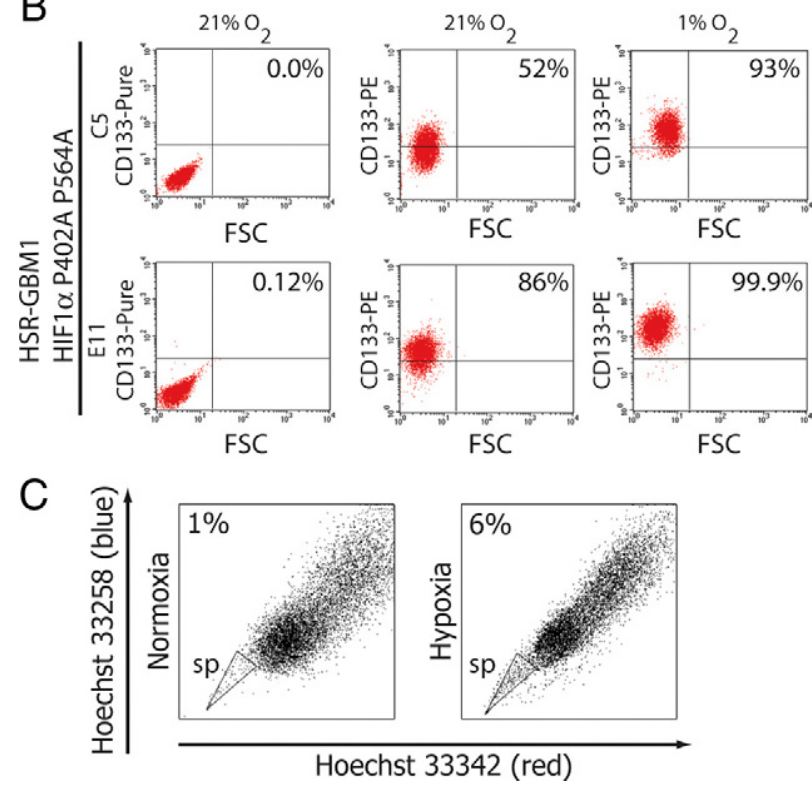

Figure 3. A: Constitutive expression of oxygen-stable HIF $1 \alpha^{\mathrm{P} 402 \mathrm{~A} / \mathrm{P} 564 \mathrm{~A}}$ (left panel) increased levels of CD133 protein expression (right panel) in HSRGBM1 C5 and E11 as compared with the vector control infected parent line (P). B: Flow cytometric analysis for CD133 of normoxic and hypoxic HSRGBM1 C5 and E11 cell lines overexpressing HIF1 $\alpha^{\mathrm{P} 402 \mathrm{~A} P 564 \mathrm{~A}}$ showed increased baseline levels of CD133 positive cells, which further increases following 24 hours of hypoxia. Unconjugated CD133 (pure) was used as threshold control. C: Side population was increased in HSR-GBM1 cultures that were exposed for 24 hour to hypoxia as compared with normoxia grown cells

induced in response to hypoxia. We have previously shown that radiation increases side population, which is associated with increased stem-like populations in GBM. ${ }^{9}$ Others have also shown that side population identifies a stem-like population in brain tumors. ${ }^{11,49,50}$ HSR-GBM1 cultures were exposed to normoxia or hypoxia for 24 hours followed by flow-cytometric analysis of side population. Hypoxia increased side-population percentages from $0.8 \%$ to $5 \%$ in uninfected HSRGBM1 cells (not shown), and from $0.9 \%$ to $6 \%$ for vector-control infected cells (Figure 3C). However, unlike CD133, side population was not increased in normoxic stable subclones expressing the mutant form of HIF1 $\alpha^{\text {P402A/P564A }}$ (data not shown).

\section{Hypoxia Increases Clonogenic Potential of GBM Cells}

Given the increase in the percentage of stem-like cells when GBM neurospheres are grown in hypoxic conditions, one would also predict a concomitant increase in tumor clonogenicity. To test this, HSR-GBM1 and HSRGBM2 cells were grown in hypoxic conditions for 24 hours followed by recovery overnight in normoxia. Equal numbers of single viable cells were then seeded in methylcellulose and grown for 10 days under normal oxygen 
A

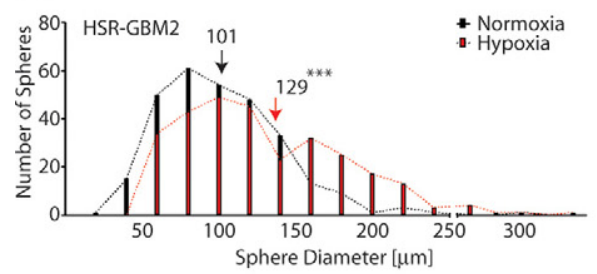

C

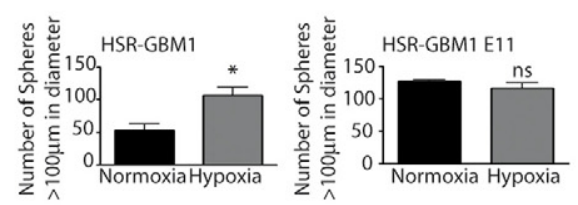

E

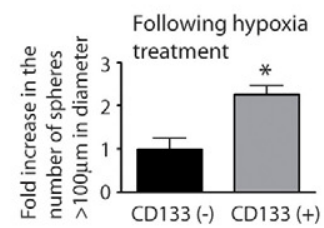

B
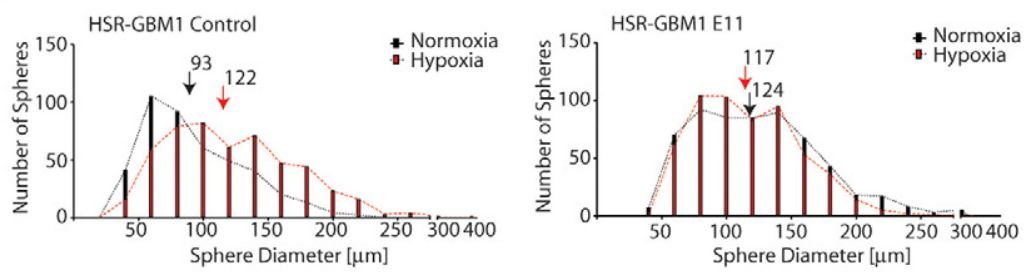

D
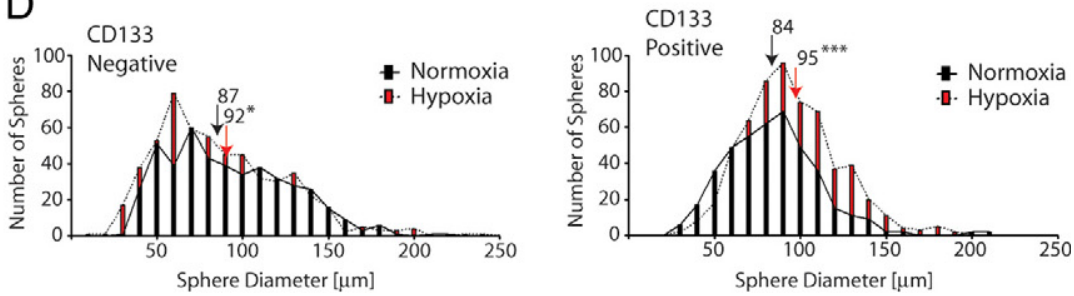

$\mathrm{F}$

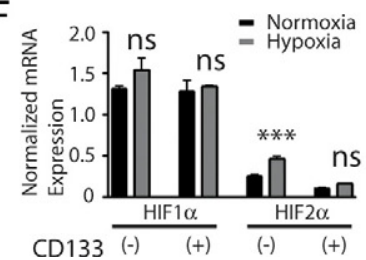

Figure 4. A: Clonogenic analysis in NSMC medium. HSR-GBM2 grown under hypoxia (red bars) for 24 hours and then plated in NSMC medium showed increased clonogenic potential compared with normoxic (black bars) HSR-GBM2 cells (**** $P<0.001$, two sided $t$-test). B: HSR-GBM1 grown under hypoxia for 24 hours and then plated in NSMC medium showed increased clonogenic potential compared with normoxic HSR-GBM1control cells $(P<0.001$, two sided $t$-test) $($ left panel). HSR-GBM1 stably expressing the oxygen-stable, HIF1 $\alpha^{\mathrm{P} 402 \mathrm{~A} / \mathrm{P} 564 \mathrm{~A}}$ showed maximal clonogenic potential (compared with normoxic cells from left panel) under normoxia (right panel). C: Quantification of the distribution analysis shown in $\mathbf{B}$. $\left({ }^{*} P<0.05\right.$, ns - not significant; two-sided $t$-test). D: Clonogenic analysis of FACS-sorted CD133 positive and negative cells showed that hypoxia affected steady-state CD133-positive cells as the average sphere diameter increases (right panel) more so than CD133-negative cells (left panel) $\left({ }^{*} P<0.05\right.$, ${ }^{* * * *} P<0.001$, two sided $t$-test). E: Hypoxia treatment of FACS-sorted CD133 positive and negative cells increased the number of colonies with diameter greater than $100 \mu \mathrm{m}$ by twofold in CD133 positive but not CD133-negative cells $\left({ }^{*} P<0.05\right.$; two-sided $t$-test). F: Quantitative real-time reverse transcription-PCR analysis of HIF1 $\alpha$ and HIF $2 \alpha$ mRNA expression in FACS sorted CD133 positive and negative cells showed that hypoxia did not affect HIF1 $\alpha$ mRNA expression but significantly increased HIF $2 \alpha$ expression in CD133 negative but not CD133 positive cells (***: $P<0.001$, ns - not significant; two-sided $t$-test)

tension. In the triplicate wells for each growth condition, ten random fields were photographed and the overall number and diameter of the neurospheres was measured in a blinded fashion. The overall number of spheres was only slightly increased in hypoxia. However, we were interested to note an overall increase in sphere diameter from $93 \mu \mathrm{m}$ to $122 \mu \mathrm{m}(P<0.001)$ for HSR-GBM1 and from 101 to $129(P<0.001)$ for HSR-GBM2 in cells grown in hypoxia before clonogenic assessment (Figure 4, A and $\mathrm{B}$, left panel).

We next investigated what this increase in neurosphere size might mean in terms of tumor biology. It has been shown that when dispersed single cells from mixed non-neoplastic neural cultures are grown in an immobilizing matrix, only the larger spheres are derived from true neural stem cells capable of serial passage. ${ }^{48} \mathrm{We}$ therefore assessed at what size HSR-GBM1 neurospheres grown in methylcellulose were capable of serial passage. We found that when single cell-derived GBM neurospheres over $100 \mu \mathrm{m}$ in size were dissociated and re-seeded, they were capable of generating both large and small "daughter" spheres, and could be passaged multiple times (see supplemental Figure S1 at http://ajp.amjpathol.org). In contrast, when spheres smaller than $50 \mu \mathrm{m}$ were dissociated, they generated only small daughter spheres, and these could not be further passaged, suggesting they had formed from progenitor cells of limited replicative potential (see supplemental Figure S1 at http://ajp.amjpathol.org). We therefore used a 100 $\mu \mathrm{m}$ cutoff to define neurospheres formed by "true" cancer stem cells. Using these criteria, the number of CSC-derived spheres increased two-fold $(P=0.01)$ for HSR-GBM1 following hypoxia, indicating that growth in low oxygen increases the clonogenic potential of GBM neurosphere cells (Figure 4, B and C, left panels).

\section{$H I F 1 \alpha, H I F 2 \alpha$, Clonogenicity, and CD133}

We next determined if the increased clonogenicity following hypoxia is HIF1 $\alpha$ mediated. To this end, we examined the clonogenic potential of the HSR-GBM1 E11 subline expressing the oxygen stable form of HIF1 $\alpha$. HSR-GBM1 E11 showed significantly increased numbers of large spheres under normal oxygen conditions, but this did not increase further in response to hypoxia (Figure 4, B and $\mathrm{C}$, right panels). These data suggest that hypoxia increases the clonogenic potential of HSR-GBM1 cells at least in part through HIF1 $\alpha$ upregulation. To determine the effect of hypoxia on CD133 positive and negative cells, HSR-GBM1 cells were sorted by FACS, exposed to hypoxia for 24 hours, and plated as described above. 
Interestingly, CD133 positive cells showed significantly increased average sphere diameter after exposure to hypoxia, with a two-fold increase in the number of spheres over $100 \mu \mathrm{m}$ in size (Figure 4D, right panel). In contrast, CD133 negative cells showed little response with almost overlapping frequency curves. Overall, the number of large spheres (diameter greater than $100 \mu \mathrm{m}$ ) increased two-fold for CD133 positive cells (Figure 4D, right panel and quantified in $4 \mathrm{E}$ ). Taken together, these data suggest that hypoxia increases the clonogenic potential of steady-state CD133 positive cells, which under normal oxygen tension will not develop into large spheres, but does not affect CD133 negative cells in the same way.

It has been recently suggested that $\mathrm{HIF} 2 \alpha$ represents a more selective mediator of CSC response to hypoxia in GBM. ${ }^{52}$ We therefore also examined the relative changes in both $\mathrm{HIF} 1 \alpha$ and HIF2 $\alpha$ mRNA expression in our GBM neurospheres cells in response to growth in reduced oxygen. After FACS sorting into CD133 positive and negative populations followed by growth in hypoxia for 24 hours, we quantitated mRNA by reverse transcriptionPCR and found that HIF1 $\alpha$ levels were relatively similar in CD133 positive and negative cell populations and were not significantly changed in response to hypoxia (Figure $4 \mathrm{~F})$. In contrast, while overall mRNA levels of HIF2 $\alpha$ were lower in comparison with $\mathrm{HIF} 1 \alpha$, they increased significantly in CD133 negative cells in response to hypoxia (Figure 4F). However, on Western blot, we were not able to reproducibly detect HIF2 $\alpha$ protein in normoxic or hypoxic conditions, although introduction of a construct encoding an oxygen-stable version of the protein produces a band of the appropriate size (data not shown). In combination with the induction of $\mathrm{HIF} 1 \alpha$ protein in reduced oxygen shown in Figure 1B, our findings suggest that while HIF2 $\alpha$ expression is more selectively induced by hypoxia at an mRNA level, at a protein level HIF1 $\alpha$ represents the major target.

One potential explanation for the increased clonogenicity following hypoxic exposure is that low oxygen concentrations kill a substantial percentage of cells and select for CSC more resistant to hypoxia. Alternatively, it is possible that hypoxia either increases the proliferation rate of CSC or affects the ratio of symmetrical and asymmetrical division, thereby altering the number of daughters that have stem-like properties. To begin to test such possibilities, we examined proliferation and apoptosis in hypoxic HSR-GBM1 from continuous or xenograft-isolated cultures. We found that cell viability and apoptosis percentages were not increased by hypoxia (see supplemental Figure S2, A and B, at http://ajp.amjpathol.org). Indeed, apoptosis seemed to decrease slightly under these conditions. In addition, in most experimental replicates we find that HSR-GBM1 cells continue to proliferate under hypoxic conditions to a similar degree as in normoxia, as assessed by MTT growth assays (see supplemental Figure S2C at $h$ ttp://ajp.amjpathol.org). These results suggest that hypoxia does not increase the CSC fraction by killing better differentiated cells.

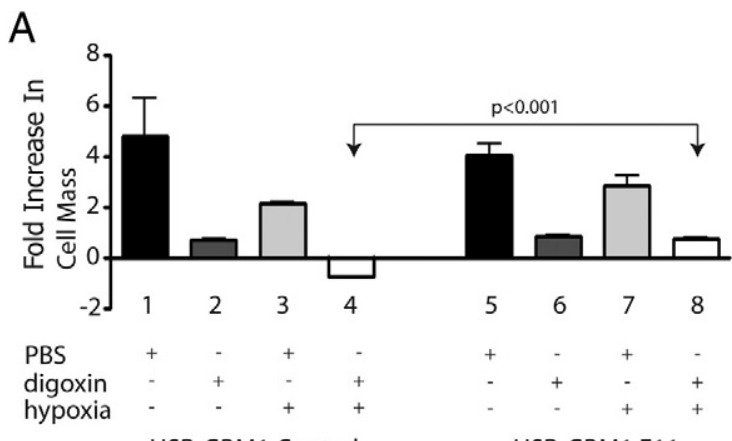

HSR-GBM1 Control

HSR-GBM1 E11

B

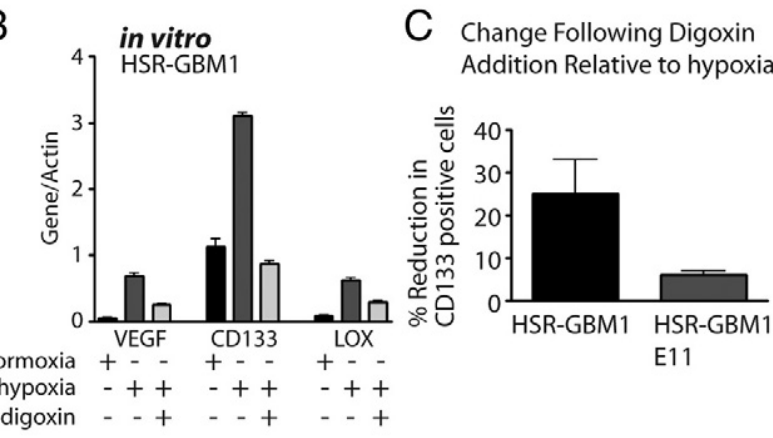

D in vitro

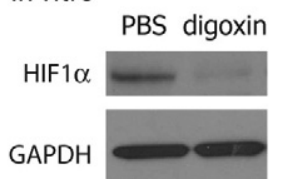

Figure 5. In vitro digoxin treatments. A: MTT [3-(4,5-dimethylthiazol-2-yl)diphenyl-tetrazolium bromide] analysis for HSR-GBM1 vector control and HIF $1 \alpha^{\text {P402A/P564A }}$ (E11) expressing cells. Growth of HSR-GBM1 was inhibited significantly in the presence of digoxin in normoxia and more so under hypoxia. Fold increase in cell mass was calculated by comparing readings on day five to those of day one. The growth of HSR-GBM1 HIF1 $\alpha^{\text {P402A/P564A }}$ was also inhibited by digoxin; however, in hypoxia, HIF $1 \alpha$ appeared to completely rescue the effect digoxin under hypoxia (compare columns six and eight to columns two and four). ( $P<0.001$, two-sided $t$-test $).$ B: Digoxin treatment reduced the expression level of the HIF1 $\alpha$ direct targets VEGF and LOX, as well as CD133. Cells were treated with hypoxia or normoxia with PBS or digoxin $(100 \mathrm{nmol} / \mathrm{L})$ for 48 hours. C: Flow cytometric analysis of HSR-GBM1 cells, either control or E11 (Expressing oxygen stable form of HIF1 $\alpha$ ), showed that digoxin treatment reduced CD133 fraction by $25 \%$ in HSR-GBM1 control cells, an effect that was partially rescued (to 6\%) by constitutive expression of the oxygen stable form of HIF $1 \alpha$. (The average of three independent experiments is shown. D: Western blot analysis for HIF $1 \alpha$ in cultured HSR-GBM1 cells treated with digoxin for 24 hours. Glyceraldehyde-3-phosphate dehydrogenase used as even loading control.

\section{Digoxin Inhibits GBM Growth in Vitro and in Vivo}

It has been recently shown that digoxin and other cardiac glycosides are potent inhibitors of hypoxia inducible factors, and can effectively block the proliferation of PC-3 (prostate adenocarcinoma) and P493-Myc (c-Myc transformed B-cell) cell lines in vitro and in vivo. ${ }^{53}$ We therefore examined the response of GBM neurospheres (Figure $5 \mathrm{~A})$ as well as established GBM and medulloblastoma cell lines propagated in $10 \%$ fetal bovine serum-containing media (see supplemental Figure S3A at http://ajp.amjpathol.org) to digoxin under normal and reduced oxygen concentrations. Most cell lines tested had their growth significantly inhibited in normal oxygen levels 
by $100 \mathrm{nmol} / \mathrm{L}$ digoxin, perhaps due to suppression of the low baseline expression of HIFs we detect in these conditions (Figure 1B). In hypoxic in vitro conditions, digoxin clearly reduced HIF1 $\alpha$ levels (Figure 5D). The effects of digoxin on growth were exacerbated under reduced oxygen concentration (Figure 5A), and HSR-GBM1 E11 cells expressing oxygen stable HIF $1 \alpha$ showed a significant $(P<0.001)$ abrogation of digoxin's growth inhibitory effects (right panel of Figure 5A). This partial rescue suggests that at least a portion of the anti-tumor effects of digoxin are mediated by HIFs. To generate additional evidence for an ongoing HIF1 $\alpha$ requirement in GBM we introduced shRNA targeting it into HSR-GBM1 cells using lentivirus (see supplemental Figure S3B at $h$ ttp://ajp. amjpathol.org). This construct reduced HIF1 $\alpha$ mRNA levels by over $90 \%$, as compared with parent cells or controls, and the cells lacking HIF1 $\alpha$, but not controls, died within two passages (data not shown). Thus in some GBM lines HIF1 $\alpha$ seems to be required for ongoing growth even in normoxia.

To further examine the effect of digoxin on the hypoxic response, we quantitated the mRNA expression levels of the known HIF1 $\alpha$ targets, VEGF and LOX, as well as of CD133. We found that digoxin treatment resulted in significant reduction in the expression of these genes (Figure 5B). Flow cytometric analysis of CD133-expressing cells confirmed that digoxin treatment inhibited the percentage of CD133 expressing cells by $25 \%$, as compared with PBS treated cells, an effect that is partially blocked in cells expressing the oxygen-stable form of $\mathrm{HIF1} \alpha$ (Figure 5C).

To test if digoxin can reduce HIF levels in GBM in vivo, mice carrying HSR-GBM1 flank xenografts were treated with i.p. injections of PBS or digoxin at $2 \mathrm{mg} / \mathrm{kg}$. Fine needle aspirate biopsies were performed just before ( 0 hours) and 2 hours after PBS or digoxin administration, and the levels of $\mathrm{HIF} 1 \alpha$ and $\mathrm{CD} 133$ were analyzed by Western blotting. Digoxin treatment significantly inhibited HIF1 $\alpha(63 \%)$ and CD133 (72\%) protein levels when compared with pretreatment samples (Figure 6A). We next examined a larger cohort of mice carrying HSR-GBM1 flank xenografts. Mice were treated daily by i.p. injections of PBS or digoxin at $2 \mathrm{mg} / \mathrm{kg}$. We found that digoxin significantly inhibited the growth of HSR-GBM1 xenografts (Figure 6B, $P<0.01$, two-sided $t$-test). While 5 of the 14 PBS treated xenografts contained necrosis, in general multiple foci with associated pseudopalisading of tumor cells (Figure 6C, left panel), only 1 of 17 digoxin treated tumors had a single necrotic focus, and this was small and lacked pseudopalisades (Figure 6C, right panel). These differences were not driven by smaller tumor sizes in the latter group, as 10 of the digoxintreated xenografts lacking necrosis were as large as the PBS-treated ones showing this feature. Interestingly the mRNA expression level of VEGF, a direct target of HIF1 $\alpha$, was significantly lower in digoxin-treated xenografts, providing further evidence that this treatment can block the hypoxic response in brain tumors (Figure 6D).

As digoxin treatment results in reduction of the hypoxia induced CD133-positive fraction (Figure 5C) we hypothesized that it may reduce engraftment of tumor cells in
A
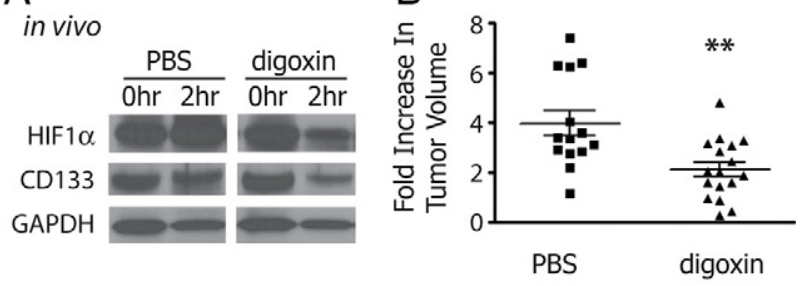

C
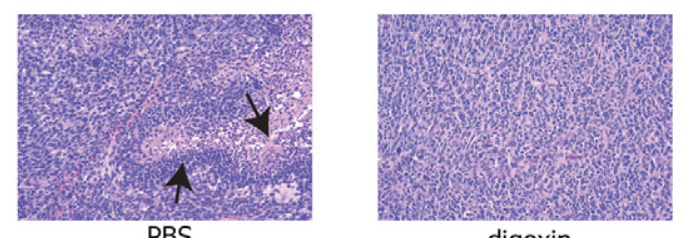

digoxin
D

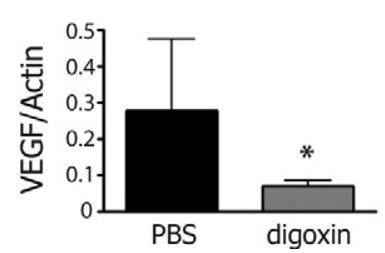

$\mathrm{E}$

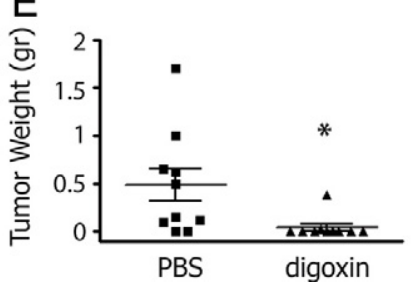

Figure 6. In vivo digoxin treatments. A: Western blot analysis for biopsies of HSR-GBM1 flank xenografts, taken before ( 0 hours) and after ( 2 hours) intraperitoneal digoxin injection $(n=2)$, show reduced protein levels for CD133 and HIF1 $\alpha$. B: Mice treated with digoxin for 14 days showed significant reduction in tumor growth rate as compared with PBS treated mice (B, **: $P<0.01$ two sided $t$-test from 14 and 17 xenografts taken from PBS- and digoxin-treated mice, respectively). C: H\&E staining of HSR-GBM1 flank xenografts treated with PBS exhibit numerous sites of palisading necrosis, which are completely absent in xenografts from mice that were treated with digoxin (arrows point to these features). D: Real-time PCR analysis for VEGF, a HIF $1 \alpha$ dependent target gene, showed a significant reduction following digoxin treatment $\left({ }^{*} P<0.05\right.$, two-sided $t$-test for pulled values from 5 PBS-treated and 6 digoxin-treated mice). E: In vitro digoxin pretreatment significantly inhibited tumor engraftment of hypoxic HSR-GBM1 cells in nude mice $\left({ }^{*} P<0.05\right.$, two-sided $t$-test for pulled values from 5 PBS-treated and 5 digoxin-treated mice).

vivo. To test this, HSR-GBM1 cells were grown in hypoxia and treated with PBS or digoxin. Cells were then allowed to recover for 24 hours under normoxic condition at which point $1 \times 10^{5}$ viable cells were injected into nude mice. We found that in vitro pretreatment with digoxin inhibited flank engraftment, with only one of ten sites injected with digoxin-treated cells growing a small xenograft. In contrast, 8 of 10 sites injected with PBS-treatment cells developed palpable flank xenografts (Figure 6E; mean weight in grams $0.48 \pm 0.17$ PBS, $0.04 \pm 0.03$ digoxin, $P<0.05$ two sided $t$-test). Taken together, these data suggest that digoxin is an effective inhibitor of GBM growth in vitro and in vivo. In addition, $\mathrm{HIF} 1 \alpha$ blockade appears capable of inhibiting the hypoxic response and the expansion and likely the viability of CSC under hypoxia.

\section{Discussion}

GBM are almost universally fatal, and the presence of a relatively small population of stem-like cells with an intrinsic resistance to chemo- and radiotherapies have been 
proposed as one reason for the current failure in treating these and other deadly cancers. ${ }^{54-61}$ Because reduced oxygen levels have been shown to promote the survival and growth of embryonic stem cells and neural stem cells, we sought to better understand the role of oxygen in CSC biology. We found that both established GBM neurosphere lines and freshly resected tumors respond to reduced oxygen by increased expression of the neural stem cell marker CD133, as well as enlargement of the CSC fraction measured by flow cytometric analysis of CD133 or side population. Additional stem cell markers such as Klf4 and Sox2 were also induced, as were ligands and targets of the Notch pathway.

Increases in CD133 expression following hypoxia have been previously reported in the U251 glioma cell line, and suggested to reflect mitochondria-related bioenergenic stress. ${ }^{62}$ However, the ability of CD133 to identify CSC in adherent glioma cell lines such as U251 is not entirely clear, and we therefore used GBM cells grown as neurospheres for our analyses. While the initial induction of CD133 was similar in both studies, in contrast to Griguer and colleagues ${ }^{62}$ we found that the increase in CD133 percentages following hypoxic exposure was a relatively stable phenomenon that could persist for at least 7 days. The relevance of CD133 in defining a putative CSC population in GBMs has been the issue of much debate in recent years, with several studies suggesting that cells lacking this marker also have the capacity to self renew and engraft. ${ }^{63-72}$ While some CD133 negative cells were able to form colonies in methylcellulose, we found that CD133 positive cells had a twofold clonogenic advantage in our neurosphere lines, suggesting that while imperfect this marker has value in prospectively identifying CSC.

We next examined the functional effects of hypoxia on tumor growth, predicting increases in clonogenicity due to the elevated percentage of cells in the cultures expressing CSC markers. Interestingly, we found that only larger spheres can be serially passaged, suggesting that sphere size must be taken into account when quantitating CSC clonogenicity. Similar to non-neoplastic stem cells, GBM neurospheres exhibited significantly increased clonogenic capacity following 24 or 72 hours exposure to hypoxia. This increased ability to form colonies following growth in reduced oxygen was restricted to CD133 positive cells, consistent with the concept that it is this subpopulation that drives formation of neurospheres. It is possible that during hypoxic exposure CD133-positive cells divide more rapidly, or shift to symmetrical cell divisions, thereby generating increased numbers of CD133-positive daughter cells and potentiating clonogenic growth.

We believe that the effects of hypoxia on CSC fraction and tumor clonogenicity are driven at least in part by increases in $\mathrm{HIF} 1 \alpha$ activity. We observed induction of this protein in GBM neurosphere lines grown in hypoxia, and expression of an oxygen-stable HIF $1 \alpha$ construct was sufficient to significantly increase both CD133 expression and clonogenicity of these cells. Importantly, when oxygen-stable HIF1 $\alpha$ is expressed in GBM neurospheres, exposure to hypoxia does not result in significant addi- tional clonogenic capacity, suggesting that $\mathrm{HIF} 1 \alpha$ alone can mediate the majority of the hypoxic effect in this context.

Some aspects of our data are similar to those recently reported by others. $\mathrm{Li}$ and colleagues ${ }^{52}$ also demonstrated that hypoxia can increase expression of CD133 and clonogenic growth in GBM neurospheres. They found that both $\mathrm{HIF} 1 \alpha$ and $\mathrm{HIF} 2 \alpha$ were induced in $\mathrm{CD} 133$ positive cells by severe hypoxia, but only HIF1 $\alpha$ levels increased in CD133 negative cells. Overall, they felt that HIF2 $\alpha$ represented a more selective target in gliomas, and one that was induced by a more modest reduction in oxygen, although as we note in the Introduction oxygen levels of $1 \%$ or less are relatively common in GBM. McCord and colleagues ${ }^{73}$ have also recently shown that lesser degrees of hypoxia (7\% oxygen) can induce stem cell markers and selfrenewal in gliomas, with increases in HIF2 $\alpha$ but not HIF1 $\alpha$ levels. Finally, Pistollato and colleagues ${ }^{74}$ found that in pediatric gliomas, $2 \%$ oxygen levels are sufficient to induce HIF1 $\alpha$ expression and inhibit differentiation of tumor cells, and that these effects were mediated by bone morphogenetic protein. While our findings with respect to hypoxia, stem cell markers and clonogenicity in glioma are consistent with these recent reports, the gain of function studies we performed using oxygen stable $\mathrm{HIF} 1 \alpha$ are unique. These suggest that $\mathrm{HIF} 1 \alpha$ expression alone is sufficient to promote the stem cell response to hypoxia in GBM neurospheres. However, as indicated above, HIF2 $\alpha$ also likely plays a significant role and it will be important in the future to better define the relative contributions of $\mathrm{HIF} 1 \alpha$ and $\mathrm{HIF} 2 \alpha$ in primary tumors.

Another novel aspect of our study was the use of digoxin to target the hypoxic response in GBM. Recently, Zhang and colleagues ${ }^{53}$ showed that digoxin, a commonly used cardiac glycoside, blocks translation of HIFs and growth of the PC3 and P493-Myc carcinoma and lymphoma cell lines in vitro and in vivo. These results suggested to us a clinically tractable method by which HIF factors could by inhibited in GBM. We found that digoxin reduced $\mathrm{HIF} 1 \alpha$ and $\mathrm{CD} 133$ protein levels, and slowed the growth of glioma cell lines in vitro, and tumor flank xenografts in vivo. Others have also shown that inhibition of $\mathrm{HIF} 1 \alpha$ by siRNA inhibits glioma growth in vitro and in vivo. ${ }^{75-77}$ The inhibition of cellular proliferation we observed was partially rescued by constitutive expression of HIF1 $\alpha$, indicating that digoxin's effect on cellular proliferation is at least somewhat dependent on blocking the hypoxic response. Consistent with this concept, we demonstrated that intraperitoneal digoxin injections blocked the expression of another important hypoxic response factor in tumor xenografts, the pro-angiogenic protein VEGF. Thus targeting the hypoxic response using digoxin may effectively suppress both angiogenic and stem-cell responses in GBM.

The evidence for using glycosides such as digoxin to treat cancer extends beyond the recent discovery that it can inhibit HIF. Digoxin and other cardiac glycosides used to treat congestive heart failure were first investigated as potential anti-cancer remedies in 1967, and Stenkvist and colleagues ${ }^{78-79}$ have shown that women with breast cancer taking digitalis had several-fold lower 
death rates. A review of plasma samples from 9271 cardiac patients revealed high concentrations of digitoxin were associated with a lower risk for leukemia, lymphoma and cancer of the urinary tract. ${ }^{80} \mathrm{~A}$ number of in vitro studies have confirmed anti-cancer effects of digoxin and other glycosides (reviewed in 78, 79). Based on these and other clinical and preclinical data, two trials involving digoxin have been initiated (Clinical Trials.gov NCT00281021 and NCT00650910).

In summary, we have found that hypoxia (1\% oxygen) promotes expansion of the CSC pool in GBM neurospheres isolated from freshly resected tumors, as well as those grown for longer periods of time. A twofold increase in tumor clonogenicity was also seen in hypoxic cultures. HIF factors played a key role in mediating these changes in CSC percentage and tumor growth, as expression of oxygen-stable $\mathrm{HIF} 1 \alpha$ can recapitulate the majority of the effects. Most importantly, the fact that digoxin can inhibit the CSC response to hypoxia suggests a novel therapeutic avenue for these extremely aggressive tumors.

\section{References}

1. Hegi ME, Diserens AC, Gorlia T, Hamou MF, de Tribolet N, Weller M, Kros JM, Hainfellner JA, Mason W, Mariani L, Bromberg JE, Hau P, Mirimanoff RO, Cairncross JG, Janzer RC, Stupp R: MGMT gene silencing and benefit from temozolomide in glioblastoma. $N$ Engl J Med 2005, 352:997-1003

2. Stupp R, Mason WP, van den Bent MJ, Weller M, Fisher B, Taphoorn MJ, Belanger K, Brandes AA, Marosi C, Bogdahn U, Curschmann J, Janzer RC, Ludwin SK, Gorlia T, Allgeier A, Lacombe D, Cairncross $J G$, Eisenhauer E, Mirimanoff RO: Radiotherapy plus concomitant and adjuvant temozolomide for glioblastoma. N Engl J Med 2005, 352:987-996

3. Galli R, Binda E, Orfanelli U, Cipelletti B, Gritti A, De Vitis S, Fiocco R, Foroni C, Dimeco F, Vescovi A: Isolation and characterization of tumorigenic, stem-like neural precursors from human glioblastoma Cancer Res 2004, 64:7011-7021

4. Hemmati HD, Nakano I, Lazareff JA, Masterman-Smith M, Geschwind $\mathrm{DH}$, Bronner-Fraser M, Kornblum HI: Cancerous stem cells can arise from pediatric brain tumors. Proc Natl Acad Sci USA 2003, 100:15178-15183

5. Singh SK, Hawkins C, Clarke ID, Squire JA, Bayani J, Hide T, Henkelman RM, Cusimano MD, Dirks PB: Identification of human brain tumour initiating cells. Nature 2004, 432:396-401

6. Dean M, Fojo T, Bates S: Tumour stem cells and drug resistance. Nat Rev Cancer 2005, 5:275-284

7. Oliver TG, Wechsler-Reya RJ: Getting at the root and stem of brain tumors. Neuron 2004, 42:885-888

8. Li X, Lewis MT, Huang J, Gutierrez C, Osborne CK, Wu MF, Hilsenbeck SG, Pavlick A, Zhang X, Chamness GC, Wong H, Rosen J, Chang JC: Intrinsic resistance of tumorigenic breast cancer cells to chemotherapy. J Natl Cancer Inst 2008, 100:672-679

9. Bar EE, Chaudhry A, Lin A, Fan X, Schreck K, Matsui W, Piccirillo S, Vescovi AL, DiMeco F, Olivi A, Eberhart CG: Cyclopamine-mediated hedgehog pathway inhibition depletes stem-like cancer cells in glioblastoma. Stem Cells 2007, 25:2524-2533

10. Fan X, Matsui W, Khaki L, Stearns D, Chun J, Li YM, Eberhart CG: Notch pathway inhibition depletes stem-like cells and blocks engraftment in embryonal brain tumors. Cancer Res 2006, 66:7445-7452

11. Piccirillo SG, Reynolds BA, Zanetti N, Lamorte G, Binda E, Broggi G, Brem H, Olivi A, Dimeco F, Vescovi AL: Bone morphogenetic proteins inhibit the tumorigenic potential of human brain tumour-initiating cells. Nature 2006, 444:761-765

12. Clement V, Sanchez P, de Tribolet N, Radovanovic I, Ruiz i Altaba A HEDGEHOG-GLI1 signaling regulates human glioma growth, cancer stem cell self-renewal, and tumorigenicity. Curr Biol 2007, 17:165-172

13. Sarangi A, Valadez JG, Rush S, Abel TW, Thompson RC, Cooper MK:
Targeted inhibition of the Hedgehog pathway in established malignant glioma xenografts enhances survival. Oncogene 2009, 28:3468-3476

14. Fan X, Khaki L, Zhu TS, Soules ME, Talsma CE, Gul N, Koh C, Zhang J, Li YM, Maciaczyk J, Nikkhah G, Dimeco F, Piccirillo S, Vescovi AL, Eberhart CG: NOTCH pathway blockade depletes CD133-positive glioblastoma cells and inhibits growth of tumor neurospheres and xenografts. Stem Cells 28:5-16

15. Chigurupati S, Venkataraman R, Barrera D, Naganathan A, Madan M, Paul L, Pattisapu JV, Kyriazis GA, Sugaya K, Bushnev S, Lathia JD, Rich JN, Chan SL: Receptor channel TRPC6 is a key mediator of Notch-driven glioblastoma growth and invasiveness. Cancer Res 70:418-427

16. Wang J, Wakeman TP, Lathia JD, Hjelmeland AB, Wang XF, White RR, Rich JN, Sullenger BA: Notch promotes radioresistance of glioma stem cells. Stem Cells 28:17-28

17. Panchision DM: The role of oxygen in regulating neural stem cells in development and disease. J Cell Physiol 2009, 220:562-568

18. Ezashi T, Das P, Roberts RM: Low O2 tensions and the prevention of differentiation of hES cells. Proc Natl Acad Sci USA 2005, 102:4783-4788

19. Studer L, Csete M, Lee SH, Kabbani N, Walikonis J, Wold B, McKay R: Enhanced proliferation, survival, and dopaminergic differentiation of CNS precursors in lowered oxygen. J Neurosci 2000, 20:7377-7383

20. Morrison SJ, Csete M, Groves AK, Melega W, Wold B, Anderson DJ: Culture in reduced levels of oxygen promotes clonogenic sympathoadrenal differentiation by isolated neural crest stem cells. J Neurosci 2000, 20:7370-7376

21. Pistollato F, Chen HL, Schwartz PH, Basso G, Panchision DM: Oxygen tension controls the expansion of human CNS precursors and the generation of astrocytes and oligodendrocytes. Mol Cell Neurosci 2007, 35:424-435

22. Hemphill JC 3rd, Smith WS, Sonne DC, Morabito D, Manley GT: Relationship between brain tissue oxygen tension and CT perfusion: feasibility and initial results. AJNR Am J Neuroradiol 2005, 26:1095-1100

23. Nwaigwe Cl, Roche MA, Grinberg O, Dunn JF: Effect of hyperventilation on brain tissue oxygenation and cerebrovenous $\mathrm{PO} 2$ in rats. Brain Res 2000, 868:150-156

24. Whalen WJ, Ganfield R, Nair P: Effects of breathing $\mathrm{O}_{2}$ or $\mathrm{O}_{2}+\mathrm{CO}_{2}$ and of the injection of neurohumors on the $\mathrm{pO}_{2}$ of cat cerebral cortex. Stroke 1970, 1:194-200

25. Jensen RL: Brain tumor hypoxia: tumorigenesis, angiogenesis, imaging, pseudoprogression, and as a therapeutic target. J Neurooncol 2009, 92:317-335

26. Birner P, Piribauer M, Fischer I, Gatterbauer B, Marosi C, Ambros PF Ambros IM, Bredel M, Oberhuber G, Rossler K, Budka H, Harris AL, Hainfellner JA: Vascular patterns in glioblastoma influence clinical outcome and associate with variable expression of angiogenic proteins: evidence for distinct angiogenic subtypes. Brain Pathol 2003, 13:133-143

27. Chi JT, Wang Z, Nuyten DS, Rodriguez EH, Schaner ME, Salim A, Wang Y, Kristensen GB, Helland A, Borresen-Dale AL, Giaccia A, Longaker MT, Hastie T, Yang GP, van de Vijver MJ, Brown PO: Gene expression programs in response to hypoxia: cell type specificity and prognostic significance in human cancers. PLoS Med 2006, 3:e47

28. Sathornsumetee S, Cao Y, Marcello JE, Herndon JE 2nd, McLendon RE, Desjardins A, Friedman HS, Dewhirst MW, Vredenburgh JJ, Rich $\mathrm{JN}$ : Tumor angiogenic and hypoxic profiles predict radiographic response and survival in malignant astrocytoma patients treated with bevacizumab and irinotecan. J Clin Oncol 2008, 26:271-278

29. Semenza GL: Targeting HIF-1 for cancer therapy. Nat Rev Cancer 2003, 3:721-732

30. Semenza GL: Intratumoral hypoxia, radiation resistance, and HIF-1. Cancer Cell 2004, 5:405-406

31. Vaupel P, Mayer A: Hypoxia in cancer: significance and impact on clinical outcome. Cancer Metastasis Rev 2007, 26:225-239

32. Evans SM, Jenkins KW, Jenkins WT, Dilling T, Judy KD, Schrlau A Judkins A, Hahn SM, Koch CJ: Imaging and analytical methods as applied to the evaluation of vasculature and hypoxia in human brain tumors. Radiat Res 2008, 170:677-690

33. Evans SM, Judy KD, Dunphy I, Jenkins WT, Hwang WT, Nelson PT, Lustig RA, Jenkins K, Magarelli DP, Hahn SM, Collins RA, Grady MS, 
Koch CJ: Hypoxia is important in the biology and aggression of human glial brain tumors. Clin Cancer Res 2004, 10:8177-8184

34. Evans SM, Judy KD, Dunphy I, Jenkins WT, Nelson PT, Collins R, Wileyto EP, Jenkins K, Hahn SM, Stevens CW, Judkins AR, Phillips P, Geoerger B, Koch CJ: Comparative measurements of hypoxia in human brain tumors using needle electrodes and EF5 binding. Cancer Res 2004, 64:1886-1892

35. Collingridge DR, Piepmeier JM, Rockwell S, Knisely JP: Polarographic measurements of oxygen tension in human glioma and surrounding peritumoural brain tissue. Radiother Oncol 1999, 53:127-131

36. Rampling R, Cruickshank G, Lewis AD, Fitzsimmons SA, Workman P Direct measurement of $\mathrm{pO}_{2}$ distribution and bioreductive enzymes in human malignant brain tumors. Int J Radiat Oncol Biol Phys 1994 29:427-431

37. Park SK, Dadak AM, Haase VH, Fontana L, Giaccia AJ, Johnson RS: Hypoxia-induced gene expression occurs solely through the action of hypoxia-inducible factor 1alpha (HIF-1alpha): role of cytoplasmic trapping of HIF-2alpha. Mol Cell Biol 2003, 23:4959-4971

38. Huang LE, Gu J, Schau M, Bunn HF: Regulation of hypoxia-inducible factor 1alpha is mediated by an $\mathrm{O}_{2}$-dependent degradation domain via the ubiquitin-proteasome pathway. Proc Natl Acad Sci USA 1998 95:7987-7992

39. Kallio PJ, Wilson WJ, O'Brien S, Makino Y, Poellinger L: Regulation of the hypoxia-inducible transcription factor 1alpha by the ubiquitinproteasome pathway. J Biol Chem 1999, 274:6519-6525

40. Zhang H, Qian DZ, Tan YS, Lee K, Gao P, Ren YR, Rey S, Hammers H, Chang D, Pili R, Dang CV, Liu JO, Semenza GL: Inaugural Article: Digoxin and other cardiac glycosides inhibit HIF- $1 \alpha$ synthesis and block tumor growth. Proc Natl Acad Sci USA 2008, 105:19579-19586

41. Zhang H, Gao P, Fukuda R, Kumar G, Krishnamachary B, Zeller KI, Dang CV, Semenza GL: HIF-1 inhibits mitochondrial biogenesis and cellular respiration in $\mathrm{VHL}$-deficient renal cell carcinoma by repression of C-MYC activity. Cancer Cell 2007, 11:407-420

42. Westerman KA, Ao Z, Cohen EA, Leboulch P: Design of a trans protease lentiviral packaging system that produces high titer virus. Retrovirology 2007, 4:96

43. Sahlgren C, Gustafsson MV, Jin S, Poellinger L, Lendahl U: Notch signaling mediates hypoxia-induced tumor cell migration and invasion. Proc Natl Acad Sci USA 2008, 105:6392-6397

44. Rasband WS: Image J, U. S. National Institutes of Health 1996-2009, Bethesda MD

45. Oltersdorf T, Elmore SW, Shoemaker AR, Armstrong RC, Augeri DJ, Belli BA, Bruncko M, Deckwerth TL, Dinges J, Hajduk PJ, Joseph MK, Kitada S, Korsmeyer SJ, Kunzer AR, Letai A, Li C, Mitten MJ, Nettesheim DG, Ng S, Nimmer PM, O'Connor JM, Oleksijew A, Petros AM, Reed JC, Shen W, Tahir SK, Thompson CB, Tomaselli KJ, Wang B, Wendt MD, Zhang H, Fesik SW, Rosenberg SH: An inhibitor of $\mathrm{Bcl}-2$ family proteins induces regression of solid tumours. Nature 2005, 435:677-681

46. Charles N, Ozawa T, Squatrito M, Bleau AM, Brennan CW, Hambardzumyan D, Holland EC: Perivascular nitric oxide activates notch signaling and promotes stem-like character in PDGF-induced glioma cells. Cell Stem Cell 6:141-152

47. Zhang XP, Zheng G, Zou L, Liu HL, Hou LH, Zhou P, Yin DD, Zheng QJ, Liang L, Zhang SZ, Feng L, Yao LB, Yang AG, Han H, Chen JY: Notch activation promotes cell proliferation and the formation of neural stem cell-like colonies in human glioma cells. Mol Cell Biochem 2008, 307:101-108

48. Eltzschig HK, Abdulla P, Hoffman E, Hamilton KE, Daniels D, Schonfeld C, Loffler M, Reyes G, Duszenko M, Karhausen J, Robinson A Westerman KA, Coe IR, Colgan SP: HIF-1-dependent repression of equilibrative nucleoside transporter (ENT) in hypoxia. J Exp Med 2005, 202:1493-1505

49. Kondo T, Setoguchi T, Taga T: Persistence of a small subpopulation of cancer stem-like cells in the C6 glioma cell line. Proc Natl Acad Sci USA 2004, 101:781-786

50. Setoguchi $T$, Taga $T$, Kondo $T$ : Cancer stem cells persist in many cancer cell lines. Cell Cycle 2004, 3:414-415

51. Louis SA, Rietze RL, Deleyrolle L, Wagey RE, Thomas TE, Eaves AC, Reynolds BA: Enumeration of neural stem and progenitor cells in the neural colony-forming cell assay. Stem Cells 2008, 26:988-996

52. Li Z, Bao S, Wu Q, Wang H, Eyler C, Sathornsumetee S, Shi Q, Cao $\mathrm{Y}$, Lathia J, McLendon RE, Hjelmeland AB, Rich JN: Hypoxia-induc- ible factors regulate tumorigenic capacity of glioma stem cells. Cancer Cell 2009, 15:501-513

53. Zhang H, Qian DZ, Tan YS, Lee K, Gao P, Ren YR, Rey S, Hammers $\mathrm{H}$, Chang D, Pili R, Dang CV, Liu JO, Semenza GL: Digoxin and other cardiac glycosides inhibit HIF-1alpha synthesis and block tumor growth. Proc Natl Acad Sci USA 2008, 105:19579-19586

54. Bao S, Wu Q, McLendon RE, Hao Y, Shi Q, Hjelmeland AB, Dewhirst MW, Bigner DD, Rich JN: Glioma stem cells promote radioresistance by preferential activation of the DNA damage response. Nature 2006, 444:756-760

55. Chang CJ, Hsu CC, Yung MC, Chen KY, Tzao C, Wu WF, Chou HY Lee YY, Lu KH, Chiou SH, Ma HI: Enhanced radiosensitivity and radiation-induced apoptosis in glioma CD133-positive cells by knockdown of SirT1 expression. Biochem Biophys Res Commun 2009, 380:236-242

56. Chiou SH, Kao CL, Chen YW, Chien CS, Hung SC, Lo JF, Chen YJ, Ku HH, Hsu MT, Wong TT: Identification of CD133-positive radioresistant cells in atypical teratoid/rhabdoid tumor. PLoS One 2008, 3:e2090

57. Diehn M, Cho RW, Lobo NA, Kalisky T, Dorie MJ, Kulp AN, Qian D, Lam JS, Ailles LE, Wong M, Joshua B, Kaplan MJ, Wapnir I, Dirbas FM, Somlo G, Garberoglio C, Paz B, Shen J, Lau SK, Quake SR, Brown JM, Weissman IL, Clarke MF: Association of reactive oxygen species levels and radioresistance in cancer stem cells. Nature 2009, 458:780-783

58. Hambardzumyan D, Becher OJ, Rosenblum MK, Pandolfi PP, Manova-Todorova K, Holland EC: PI3K pathway regulates survival of cancer stem cells residing in the perivascular niche following radiation in medulloblastoma in vivo. Genes Dev 2008, 22:436-448

59. Lu KH, Chen YW, Tsai PH, Tsai ML, Lee YY, Chiang CY, Kao CL, Chiou SH, Ku HH, Lin CH, Chen YJ: Evaluation of radiotherapy effect in resveratrol-treated medulloblastoma cancer stem-like cells. Childs Nerv Syst 2009, 25:543-550

60. Phillips TM, McBride WH, Pajonk F: The response of CD24(-/low)/ CD44+ breast cancer-initiating cells to radiation. J Natl Cancer Inst 2006, 98:1777-1785

61. Woodward WA, Chen MS, Behbod F, Alfaro MP, Buchholz TA, Rosen JM: WNT/beta-catenin mediates radiation resistance of mouse mammary progenitor cells. Proc Natl Acad Sci USA 2007, 104:618-623

62. Griguer CE, Oliva CR, Gobin E, Marcorelles P, Benos DJ, Lancaster $\mathrm{JR} \mathrm{Jr}$, Gillespie GY: CD133 is a marker of bioenergetic stress in human glioma. PLoS One 2008, 3:e3655

63. Beier D, Hau P, Proescholdt M, Lohmeier A, Wischhusen J, Oefner PJ, Aigner L, Brawanski A, Bogdahn U, Beier CP: CD133(+) and CD133(-) glioblastoma-derived cancer stem cells show differential growth characteristics and molecular profiles. Cancer Res 2007, 67:4010-4015

64. Jaksch M, Munera J, Bajpai R, Terskikh A, Oshima RG: Cell cycledependent variation of a CD133 epitope in human embryonic stem cell, colon cancer, and melanoma cell lines. Cancer Res 2008, 68:7882-7886

65. Joo KM, Kim SY, Jin X, Song SY, Kong DS, Lee JI, Jeon JW, Kim MH, Kang BG, Jung Y, Jin J, Hong SC, Park WY, Lee DS, Kim H, Nam DH: Clinical and biological implications of CD133-positive and CD133negative cells in glioblastomas. Lab Invest 2008, 88:808-815

66. Clement V, Dutoit V, Marino D, Dietrich PY, Radovanovic I: Limits of CD133 as a marker of glioma self-renewing cells. Int J Cancer 2009, 125:244-248

67. Sun $\mathrm{Y}$, Kong W, Falk A, Hu J, Zhou L, Pollard S, Smith A: CD133 (Prominin) negative human neural stem cells are clonogenic and tripotent. PLoS One 2009, 4:e5498

68. Kelly JJ, Stechishin O, Chojnacki A, Lun X, Sun B, Senger DL, Forsyth P, Auer RN, Dunn JF, Cairncross JG, Parney IF, Weiss S: Proliferation of human glioblastoma stem cells occurs independently of exogenous mitogens. Stem Cells 2009, 27:1722-1733

69. Nishide K, Nakatani Y, Kiyonari H, Kondo T: Glioblastoma formation from cell population depleted of prominin1-expressing cells. PLoS One 2009, 4:e6869

70. Wang J, Sakariassen PO, Tsinkalovsky O, Immervoll H, Boe SO, Svendsen A, Prestegarden L, Rosland G, Thorsen F, Stuhr L, Molven A, Bjerkvig R, Enger PO: CD133 negative glioma cells form tumors in nude rats and give rise to CD133 positive cells. Int J Cancer 2008, 122:761-768

71. Ogden AT, Waziri AE, Lochhead RA, Fusco D, Lopez K, Ellis JA, Kang J, Assanah M, McKhann GM, Sisti MB, McCormick PC, Canoll 
$\mathrm{P}$, Bruce JN: Identification of A2B5+CD133- tumor-initiating cells in adult human gliomas. Neurosurgery 2008, 62:505-514; discussion 514-505

72. Piccirillo SG, Combi R, Cajola L, Patrizi A, Redaelli S, Bentivegna A, Baronchelli S, Maira G, Pollo B, Mangiola A, DiMeco F, Dalpra L, Vescovi AL: Distinct pools of cancer stem-like cells coexist within human glioblastomas and display different tumorigenicity and independent genomic evolution. Oncogene 2009, 28:1807-1811

73. McCord AM, Jamal M, Shankavarum UT, Lang FF, Camphausen K, Tofilon PJ: Physiologic oxygen concentration enhances the stem-like properties of CD133+ human glioblastoma cells in vitro. Mol Cancer Res 2009, 7:489-497

74. Pistollato F, Chen HL, Rood BR, Zhang HZ, D'Avella D, Denaro L, Gardiman M, te Kronnie G, Schwartz PH, Favaro E, Indraccolo S, Basso G, Panchision DM: Hypoxia and HIF1alpha repress the differentiative effects of BMPs in high-grade glioma. Stem Cells 2009, $27: 7-17$
75. Fujiwara K, Iwado E, Mills GB, Sawaya R, Kondo S, Kondo Y: Akt inhibitor shows anticancer and radiosensitizing effects in malignant glioma cells by inducing autophagy. Int J Oncol 2007, 31:753-760

76. Gillespie DL, Whang K, Ragel BT, Flynn JR, Kelly DA, Jensen RL: Silencing of hypoxia inducible factor-1alpha by RNA interference attenuates human glioma cell growth in vivo. Clin Cancer Res 2007 13:2441-2448

77. Jensen RL: Hypoxia in the tumorigenesis of gliomas and as a potential target for therapeutic measures. Neurosurg Focus 2006, 20:E24

78. Al-Ghoul M, Valdes R Jr: Mammalian cardenolides in cancer prevention and therapeutics. Ther Drug Monit 2008, 30:234-238

79. Newman RA, Yang P, Pawlus AD, Block KI: Cardiac glycosides as novel cancer therapeutic agents. Mol Interv 2008, 8:36-49

80. Haux J, Klepp O, Spigset O, Tretli S: Digitoxin medication and cancer; case control and internal dose-response studies. BMC Cancer 2001, 1:11 